\title{
GW23-e1505 THE RELATIONSHIP BETWEEN PROTEINURIA AND THE SERUM ALDOSTERONE CONCENTRATION IN ALDOSTERONE-PRODUCING ADENOMA PATIENTS
}

doi:10.1136/heartjnl-2012-302920r.6

Ma Xuan, Li Hong-jian, Wang Hong-mei, Wang Meng-hui, Wang Lei, Hu Jun-li, Li Nang-fang. Hypertension Institute of Xinjiang

Objectives To analyse the relationship between $24 \mathrm{~h}$-urine protein level and serum aldosterone concentration in aldosterone-producing adenoma (APA) patients.

Methods Data of 32 APA patients who were confirmed by postoperative pathological diagnose were collected in the hypertension department of the people's hospital of Xinjiang Uygur autonomous region form June 2006 to March 2010. The patients were divided into three groups according to the tertile of serum aldosterone concentration ( $\leq 14.95 \mathrm{ng} / \mathrm{dl}, 14.96 \mathrm{ng} / \mathrm{dl}-24.71 \mathrm{ng} / \mathrm{dl}$ and $\geq 24.72 \mathrm{ng} / \mathrm{dl}$ ). The $24 \mathrm{~h}$-urine protein level of three groups were compared. Furthermore, the relationship between $24 \mathrm{~h}$ urine protein level and serum aldosterone concentration were analysed.

\section{Results}

1. Compared with the patients in the first ( $\mathrm{Lg}$ ( $24 \mathrm{~h}$-urine protein level): $0.87 \pm 0.28 \mathrm{~g} / 24 \mathrm{~h}$ ) and the second group ( $\mathrm{Lg}$ (24 h-urine protein level): $1.09 \pm 0.27 \mathrm{~g} / 24 \mathrm{~h}$ ), the patients in the third group ( $\mathrm{Lg}$ ( $24 \mathrm{~h}$-urine protein level): $1.51 \pm 0.50 \mathrm{~g} /$ $24 \mathrm{~h})$ had higher 24-proteinuria levels $(\mathrm{p}<0.05)$.

2. The Pearson correlation analysis showed that 24-h urine protein level was remarkably positively correlated with the serum aldosterone concentration in APA patients. $(r=-0.491$, $\mathrm{p}<0.01$ ).

Conclusions The proteinuria of the APA patients was positively correlated with the serum aldosterone concentration. 